\title{
Strategy to Improve Competence of Public Service Officials in the West Sulawesi Province, Indonesia
}

\author{
Dra. Rohana Thahier, M.Si \\ Senior Lecture: School of Public Administration, Institute of State Administration \\ (Doctoral Program Student at Universitas Negeri Makassar, Indonesia) \\ Ph : +628124212150 email : rohana.thahier@yahoo.co.id
}

Received: June 06, 2013 Accepted: June 27, 2013 DOI: 10.5296/jpag.v3i2.3827

\begin{abstract}
The high level of public complaints against bureaucracy shows that on the one hand the quality of bureaucratic service has, in public opinion, been found wanting. At the same time, public awareness has continued to grow, with consumers demanding they have rights to receive high quality service (Dwiyanto, 2002). The quality of public service is lacking. Often bribes are required, services are not guaranteed, and procedures are over-complicated. The perceptions of the public human resource sector are various: Professionalism is lacking, corruption, collusion and nepotism run rampant, wages are insufficient, service to the public is over-complicated, relationships are based on a patrion-client system, and there is lack of creativity and innovation, not to mention other potential negative perceptions which essentially show that this system is still weak in Indonesia. All this motivates us to reform the public human resources sector of Mamuju Regency, West Sulawesi (Reformation of Bureaucracy).
\end{abstract}

Keywords: Public Governance, Not-for-Profit, Principle-Based, Assurance, Shared Governance, Sustainable Balance, Values and Beliefs 


\section{Introduction}

With the enactment of Law No. 32 Year 2004 on Regional Government basically has given greater authority and great responsibility in governance in the region. This suggests that local governments are required to be more prepared in every way, especially with regard to personnel (employees) in carrying out a broad and complex authority in a professional, effective and efficient manner.

Upheavals are arising in connection with public discontent against the public administration. These have occurred in various regions of Indonesia due to a sense of dissatisfaction regarding local government and government services. The performance of public services is considered deficient by the community. People are starting to question the value they receive for services performed by government personnel. Although the regular budget and the development budget are growing, people do not seem satisfied with the quality of services provided by government agencies.

There are at least three causes for an increase in public discontent regarding public services, including social, economic, and political changes. In the social realm, improving public education causes the public to increase their knowledge regarding their obligations and rights in governance. In the economic sphere, rising incomes lead them to easily spend their income for the purposes of telecommunications facilities, accessing information from various sources on the performance of government, and then compare the behavior of officials from one region to those of another region. In politics, democratization of the government has caused society to become more and bolder, even to make corrections to the behavior of government officials, who are more oriented toward specific interest groups in governance.

To that end, the apparatus of civil servants are required to have adequate professionalism and competence in order to provide a quality service, in line with community expectations. Efforts to improve the quality of the performance of services by civil officials continue, both on operational and managerial levels. Various types of education and training have been undertaken by local government in Mamuju. These efforts are generally intended to improve the professionalism of the apparatus in order to carry out the task of serving the community.

But in reality, the expectations and demands of the community to get quality service from the local government officials in Mamuju, especially civil servants, have not been fully realized. This phenomenon suggests that, on the one hand the higher aspirations are in line with increasing levels of public awareness and education. On the other hand, it shows the contradictions of unpreparedness of local government officials toward the demands and expectations of the community. The conditions mentioned above, among others, were caused by the lack of standards for competence that must be exhibited by civil servants in carrying out their function and role as public servants.

If we agree with the assessment that some civil servants cannot be called professional or do not exhibit professional character, one of which being a lack of competence, then a competence test for civil service positions must be carried out. 


\section{Human Resources Management Competency-based}

Every organization, private or public needs to establish professionalism and competence among its human resources personnel. HR who are highly competent will be a center of excellence to support the organization and organizational competitiveness in entering the era of globalization and a business environment with social conditions that are changing quickly.

The role of HR in the organization is just as important as the work itself, and so the interaction between the organization and its HR managers should be a main focus of attention. Therefore, the values that comply with the demands of the organization need to be introduced and disseminated to all individuals within the organization.

Various changes have consequences for organizational change, including the following (Kusumastuti, 2003:2): 1. Technological improvements and social and lifestyle changes; 2. The shift towards a digital economy, e-commerce, which requires special knowledge and skills; 3. Intensified global competition; 4. The market is fragmented by coveringa broad geographic area, thus requiring a clear definition of the field; 5. The discrimination that separates workers and customers based on race, sex, country, and culture will be increasingly challenged.

The conditions above, require the organization to be able to adapt quickly as well. One of the strategies for organizational change is through human factors engineering. HR is increasingly perceived as important for creating a lasting competitive edge, because quality people can always survive competition in any situation. Humans have the ability to adapt and thrive and create value in the product or services they produce. Therefore, each organization must be able to respond to changes that occur through a variety of innovations, so that the organization has the necessary HR competencies.

\section{a. Concept of Competence}

Spencer (1993:9) defined competence as a basic human characteristic that affects real experience or can be used to estimate performance at work or ability to resolve issues affecting a specific situation, and competence is also a deep part of the personality and the inherent individual self that can predict one's behavior and performance in a variety of situations and jobs, and competence also has a distinguishing criterion which is used to distinguish high-performing individuals from low-performing individuals in a variety of contexts.

Allan Trayes in Murly (1997:21) defines competence as the capability of a person to use their skills, attitudes, and abilities to achieve the most effective performance.

Davis (1999:301) contributes that competence is a reflection of a person's skills and knowledge, especially with regard to the abilities and skills needed by a business in order to lower costs and provide better service to customers (more for less).

David Ulrich (1998:15-26) explicitly states that competence is seen as a factor in forming an organization's intellectual capital. Further he saysthat "Intellectual Capital = Competence $\mathrm{x}$ Commitment". In this context, competencies or human capital is seen as a combination of knowledge, skills, and abilities of individual members of an organization which can be used 
to generate professional services.

According to Longeneeker (1999:503) the services performed by an organization can generate a good service as long as the officers have a strong commitment to their work.

All things considered, competence is a fundamental factor that needs to be owned by an organization, so as to have more capabilities and make it stand out from people and groups who have average or ordinary ability. Comprehensive competence is comprised of: 1) motives, the basic needs of a person which direct their perspective actions, 2) basic properties that determine how a person acts / behaves, 3) personal image, one's perspective on the identity of his own personality (inner-self); 4) The role of civil society, how a person sees himself in interaction with others (outer-self), 5) knowledge, which can be used in a specific task / job, and 6) skills, technical ability to do any work better.

Competence position means the ability of local government officials who should have someone local government officials in the form of knowledge, skills, attitudes and behaviors required in the performance of its duties. A job or position can be done well if the holder of the relevant job or position competencies required in the task or job. The more severe the higher the job or position, then their competence (Required) must be greater. This is consistent with the higher positions and or duties and responsibilities of an officer, the greater the reward and punishment or severe dedicated to him.

Being competence according Hartojo Putro (2003) among others, can be seen in the forms capabilities: 1) understand the relevant development paradigm in efforts to achieve good governance and achieve the goals of the nation, 2) Formulate policies programs and activities in accordance with the vision, mission, and strategies adopted; 3) Understand and define the principles of governance in a harmonious and integrated; 4) Understand and explain the diversity of cultural social environment in order to improve the image and performance of the organization; 5) to actualize the ethical code in the increased professionalism of civil servants, morality, and ethics work, 6) Implement policies and overall program management activities including reporting accountability; 7) Prepare and or take decisions in the implementation or management of policies and services in accordance with its responsibilities; 8) Increase accountability and productivity of the apparatus.

\section{b. Competence Indicators Apparatus}

Basically competence is a description of the skills, knowledge and attitudes necessary to achieve the primary effective performance in the job (Baso, 2003). In the era of globalization and regional autonomy, competence of local government officials can be traced (assessment) through knowledge of the indicators are: 1) The background and educational level of the apparatus, 2) the ability to think and 3) understand the job well. While the indicator skills in question are: 1) Mastery and expertise, 2) ability to work in groups and work quality. Similarly, the attitude, the indicators are: 1) honesty, 2) the ability to empathize, and 3) the ability to control themselves. 
c. Public Service

Various definitions of public services such as Zauhar (2001:2) says that public service is an attempt to help or benefit to the public through the provision of goods or services needed by them. According Moenir (1996:4) service is everything to meet the needs of human life trying, either through its own activities and indirectly through the activities of others.

In the public service Moenir (1996:190) divides three parts, namely: 1) oral layalan, 2) writing services, and 3) service with deeds. The third part of the service is not always stand alone, but in combination with each other.

Public services according Sinambela (2005:5) is as any activity undertaken by the government against a man who has any profitable activity in a collection or entity, and offers a satisfaction even though the results are not tied to a physical product.

Agung Kurniawan (2005:6) says that public service is the provision of services (serve) for the other person or people who have an interest in the organization in accordance with the basic rules and procedures that have been established.

The definition of public services according to Kep. Menpan No. 25 of 2004 is all the service activities undertaken by public service providers as addressing the needs of service recipients, as well as in the implementation of the provisions of the legislation. While Kep. Menpan Number 58 Year 2002 classifies three types of services from government agencies and state / local enterprises. Grouping these types of services based on the characteristics and nature of its services and products are produced, namely: 1) administrative services, 2) service items, 3) services.

The three regulations issued by the government through the Ministry of Administrative Reform of public services is a customer oriented or public (society) served. It is expressly stated in the body of the regulation. In the sense that if the performance of public service agencies by the regulations also customer orientation, the attention of the public service personnel must be oriented to the public.

The statement above, reflects an orientation towards the customer, the customer is the determinant of the view that the peak of the nature and success of one's organization, a view that distort traditional views about the organization. This perspective is the perspective of customer service.

\section{Mamuju (West Sulawesi)}

Mamuju located west of the island of Sulawesi, according to Law Decree 26 of 2004 dated October 5, 2004 the Mamuju with four other districts, namely: Polewali Mandar, Majene, Mamasa and North Mamuju officially became a province of West Sulawesi provincial capital is located at Mamuju.

Mamuju is the largest region in the province of West Sulawesi. Mamuju geographically located at position: 0045 'to 20 55' south latitude and 45 'to 119050 ' East Longitude.

Mamuju borders: 1. In the North: North Mamuju, 2. In the East: North Luwu (South Sulawesi), 3. In the south: Kab.Majene, Polewali Mandar and Tator (South Sulawesi), 4. In 
the West: Makassar Strait (East Kalimantan).

District has an area of 801,406 ha Mamuju. Administratively, Administration Mamuju divided into 16 districts, 155 Rural / Urban and 2 UPT (Transmigration Settlement Units). Mamuju, is one of regencies in South Sulawesi and after the expansion is currently being held in the province of West Sulawesi, according to Law. 26 In 2004, along with Polewali Mandar, Majene, Mamuju North and Mamasa district, as well as in the Act - Act No.. 26 was designated as the capital Mamuju West Sulawesi province.

Mamuju located in West Sulawesi province at position 1038 '110" - 20 54' 552" south latitude and 11054 '47" - 130 5' 35" East longitude of Jakarta; (00 0 '0" Jakarta = 160048 '28" East longitude Green Wich). Mamuju its capital in Mamuju, bordering the North Mamuju Luwu north and north east, District Majene, Mamasa district and Tana Toraja in the south and the Makassar Strait to the west.

Mamuju with an area of 794,276 hectares, is divided into 16 administrative districts, comprising of 143 villages, 10 villages and 2 UPT Kalumpang District is the largest district with an area of $1731.99 \mathrm{~km} 2$ or 21.81 percent of the total area of Mamuju. Sub Balabalakang total area $21.86 \mathrm{~km} 2$ or 0.28 percent is the smallest district in Mamuju. Almost all Districts in Mamuju crossed by rivers. District of the most traversed the river is 12 Sub Bonehau to cross the river.

Mamuju has a hilly area. As for the mountains, in Mamuju only in the two Sub District and District Budong Budong Kalumpang.

Among the 16 districts in Mamuju, capital of the district which is located furthest away from the district capital is the capital of the district Balabalakang far as $202 \mathrm{~km}$ while the nearest district capital of the district capital is the District Simboro within 6 miles of Mamuju.

Rainfall in Mamuju highest in September amounted to $17570 \mathrm{~mm} 3$ with rainy days as much as 11 days. While the lowest rainfall occurred in January of $2781 \mathrm{~mm} 3$ with the number of rainy days is 6 days.

\section{Knowledge}

Knowledge is a process aimed at educating the nation as the capital of Indonesia's human development quality. Martopo (2004:187) argues that, in improving individual competencies of human resources, knowledge plays an important role in influencing the level of education, the ability to think and understand a good job in carrying out duties and functions within an organization work.

Indicates that the knowledge in accordance with the national education system is one of the considerations that need attention in doing an individual recruitment of qualified human resources. Strategy to improve the competency of human resources is determined by knowledge. Knowledge becomes an absolute requirement to be considered, as a benchmark in improving the competence of human resources.

Hasan (2003:12) the importance of knowledge in the human resource, indispensable. Given the knowledge to contribute in the conduct or organization of community empowerment. Knowledge cannot be separated from the three elements, namely ditamati education level, 
educational background which is owned and occupied disciplines.

Based on the table above shows that respondents about educational background and level of education; ability to think and how to understand a good job at Mamuju district showed the highest to the lowest scoring began in the category Self-sufficient with a frequency of 24 or $41 \%$, then the Adequate category with a score of 20 or $34 \%$, category Insufficient 9 or $16 \%$, then the category Very Adequate much as 3 or $5 \%$ and category Inadequate 2 or $3 \%$. With an average rating of 3.22 or Adequate qualify. It can be concluded that the ability to think local government officials in carrying out their main duty in the category quite well.

Furthermore, to see the responses on the ability to think actively develop knowledge and develop a curiosity for new things and keep up to date with the latest from a certain area of knowledge on all respondents showed the highest scoring to lowest scoring category is Adequate frequency response has the highest with a score of 26 or $45 \%$, then the category of Self-sufficient with a frequency of 18 or $31 \%$. Categories Very Adequate by 13 or $22 \%$, and inadequate by 1 or $2 \%$. With an average rating of 3.86 or $\log$ on Adequate criteria. It can be concluded that the ability to understand the work of local government officials in carrying out their main duty is to the good category.

The respondents with good understanding of the work associated with the job in giving / donate their knowledge to others in the overall respondents showed the highest scoring to lowest scoring is Adequate category with a score of 26 or $45 \%$, Self-sufficient with score of 18 or $31 \%$, Very Adequate with a score of 12 or $21 \%$, and Insufficient by a score of 2 or $3 \%$. With an average rating of 3.83 or log on Adequate category. It can be concluded that the ability of understanding a good job in completing the work of local government officials in carrying out their main duty is to the good category.

The respondents understanding of the history and customs of the organization to support the smooth achievement of the overall organization of the respondents showed the highest scoring to lowest scoring is Adequate category with a score of 25 or $43 \%$, Self-sufficient with a score of 17 or $29 \%$, Very Adequate with a score of 14 or $24 \%$, and Insufficient by 1 or $2 \%$. With an average rating of 3.86 or $\log$ on Adequate criteria. It can be concluded that the understanding of local government officials about the history and customs in supporting the smooth achievement of organizational goals that are in the good category.

Overall, the average scoring of the variables of knowledge of local government officials in Indonesia amounted to (3.69). This means that overall the variables of a working knowledge of local government officials in Mamuju in the category of Adequate.

\section{Skills}

According Pradiansyah (1999:59) skill is an ability possessed by employees in performing their duties in accordance with the principal areas of work are occupied. Skills someone based on their talents, interests, habits and interests to be achieved. This forms a reliable employee skills in developing work activities, proficient in the skills possessed and experts in the occupied areas. Sulastyo (2000:154) stated that skills play an important role in increasing the motivation of human resources. Skills are determined by: (1) reliability completing basic tasks on time, (2) competent in the skills of the work process, and (3) has expertise in the 
application of basic tasks.

Thus it can be said that the very skills needed to improve performance. Reliability, skill and expertise are the elements of the skills necessary to demonstrate that human resources have the potential to be developed to achieve organizational goals.

One dimension of the competence of employees is a skill which the competencies required to be owned by every employee. In the theory of independence (independent theory) proposed by Wankel (2000:149) states that independence is literally derived from the human resources skills of creating a variety of opportunities and creations to enhance employee performance. To view the responses of skills in government personnel competency needs districts / cities in Indonesia can be seen that the responses about the ability of the skills from the basic level to expert derived from specialized education and experience in a particular field to set up a variety of complex organizational units on the overall respondents showed the highest scoring to lowest scoring category is Self-sufficient with a score of 33 or $57 \%$, then the Adequate category with a score of 15 or $26 \%$, Insufficient by 7 or $12 \%$, Very Adequate with a score of 2 or $3 \%$, and inadequate by 1 or $2 \%$. With an average rating of 3.17 or $\log$ on Self-sufficient criterion. It can be concluded that the ability of skills from basic to expert level are derived from specialized education and experience in a particular field to set the various organizational units in the entire complex in the category of Self-sufficient.

to see the responses on the ability to perform activities more closely and different previously that the responses of the ability to determine and implement activities more thoroughly and earlier differ on the overall respondents showed the highest scoring to lowest scoring category is Self-sufficient with a score of 27 or 47\%, Adequate category with a score of 17 or $29 \%$, Very Adequate 10 or $17 \%$, and Insufficient by a score of 4 or $7 \%$. With an average rating of 3.57 or $\log$ on Adequate criteria. It can be concluded that the local government capacity to implement activities more closely in the category of good.

the responses of the local government capacity to ensure quality work, where work procedures, duties, and work can be seen that the responses of the local government capacity to ensure quality work, where work procedures, duties, and work: in all respondents showed the highest scoring to lowest scoring category is Self-sufficient with a score of 23 or $40 \%$, Adequate with a score of 20 or $34 \%$, Very Adequate with a score of 14 or $24 \%$, with an average value of 3.79 or $\log$ on Adequate criteria. It can be concluded that the local government capacity in the quality of his work, which work procedures, the tasks and the work is in the good category.

The responses of the local government capacity to influence and persuade others to follow the provisions set out in the working group and completed the task in groups and share information that is useful and relevant to members of the team can be seen the responses of the local government capacity to influence others to follow the provisions set out in the working group as well as useful and relevant information for team members on the overall respondents showed the highest scoring to lowest scoring category is Self-sufficient with a score of 25 or $43 \%$, Adequate with a score of 23 or $40 \%$, Very Adequate with a score of 8 or $14 \%$, and Insufficient with a score of 2 or $4 \%$. With an average value of 3.64 or $\log$ on 
Adequate category. It can be concluded that the local government capacity to influence and persuade others to follow the provisions set out in the working group and share useful and relevant information for the members of the team are in the good category.

the responses of the local government capacity to do a deal with related parties of the work to be performed can be seen that the responses of the local government capacity to do a deal with the relevant parties regarding the work to be performed on the entire locus showed the highest scoring to lowest scoring is Adequate category with a score of 24 or $41 \%$, please adequate with a score of 19 or $33 \%$, Very Adequate with a score of 10 or $17 \%$, Less Adequate with a score of 4 or $7 \%$. With an average rating of 3.66 or $\log$ on Adequate criteria. It can be concluded that the local government capacity to do a deal with related parties regarding the work to be carried out are in the good category.

The responses of the local government capacity to test every solution is applied, solicit feedback on its usefulness and effectiveness of creative solutions can be seen that the responses of the local government capacity to test every solution is applied, solicit feedback and creative solutions for their usefulness on the overall effectiveness of the loci showed the highest scoring to lowest scoring category is Self-sufficient with a score of 33 or 57\%, Adequate with a score of 14 or $24 \%$, Very Adequate with a score of 6 or $10 \%$, and Insufficient with a score of 4 or $7 \%$. With an average value of 3.34 or go to the category of Self-sufficient. It can be concluded that the local government capacity to test every solution is applied, solicit feedback on its usefulness and effectiveness of creative solutions that are in the good category.

Overall, the average scoring of the sub-variables skills Mamuju district government officials amounted to (3.53). This means that overall the sub variables skills Mamuju district government officials are in the Adequate category.

\section{Attitude}

Attitude is an essential part of one's personality, but a number of theories try to account for the formation and change of attitudes. One theory states that people "seek compatibility between faith by his feelings for the object" and argued that attitude change depends on the change of feelings or beliefs. Furthermore, the theory assumes that people have the attitude structure that is composed of various components of an effective and koqnitif. Coherence of these components means that changes in the other components.

Rivai (2004:247), says that attitude is a readiness to respond to, a complete framework to establish a distinctive beliefs or opinions and attitudes are also evaluative statements, whether favorable or unfavorable concerning objects, people or events. While human behavior is as a function of the interaction between the individual and his environment. Individuals bring order in the form of organizational skills, personal trust, respect, needs and past experiences.

Opinions on the attitudes and behaviors strongly associated with good or bad tasks implemented an employee, without a good attitude and behavior of the individual is unable to produce an outcome is effective and efficient. Attitudes related to employee morale which employees have demonstrated professionalism in carrying out the tasks assigned by the leadership in improving performance. To view the responses about attitudes in the strategy to 
improve the competence of government officials districts / cities in Indonesia can be seen that the responses of the local government capacity to serve a customer oriented locus showed the overall highest scoring to lowest scoring category is Self-sufficient with a score of 22 or $38 \%$, Adequate with a score of 19 or $33 \%$, Very Adequate with a score of 14 or $24 \%$, Less Adequate with a score of 2 or $3 \%$. With an average rating of 3.74 or log on Adequate category.

Furthermore, to see the responses of local government officials Empathizing Ability to others who demonstrate a balanced view of the strengths and weaknesses of a particular person can be seen that the responses of local government officials the ability to empathize with others that show a balanced view of the strengths and weaknesses of a person at a particular locus showed the overall highest scoring to lowest scoring is Adequate category with a score of 27 or $47 \%$, Self-sufficient with a score of 24 or $41 \%$, Very Adequate with a score of 3 or $4 \%$, and Insufficient with a score of 3 or $4 \%$. With an average rating of 3.48 or log on Adequate criteria.

The responses of the local government capacity to delegate authority and responsibility to a subordinate can be seen that the responses of the local government capacity to delegate authority and responsibility to a subordinate at the whole locus showed the highest scoring to lowest scoring is Adequate category with a score of 25 or $43 \%$, Self-sufficient with a score of 18 or $31 \%$, Insufficient with a score of 7 or $12 \%$, Very Adequate with a score of 6 or $10 \%$, and the category Inadequate premises score of 1 or $2 \%$. With an average rating of 3.45 or log on Adequate category.

To see the responses of the local government capacity restraint in using its authority can be seen that the responses of the local government capacity restraint in using its authority to the entire locus showed the highest scoring to lowest scoring is Adequate category with a score of 28 or $48 \%$, Self-sufficient with a score of 17 or $29 \%$, Very adequate with a score of 9 or $16 \%$, and Insufficient with scores of 2 or $3 \%$. With an average rating of 3.69 or log on Adequate category.

The responses of the local government capacity to adjust and work effectively in different situations and conditions can be seen that the responses of the local government capacity to adjust and work effectively in different situations and conditions the entire locus showed the highest scoring to lowest scoring is Adequate category with a score of 29 or 50\%, Self-sufficient with a score 21 or $36 \%$, Very Adequate with a score of 5 or $9 \%$, and Insufficient by a score of 2 or $3 \%$. With an average rating of 3.60 or $\log$ on Adequate criteria.

The responses of the local government capacity to align attitudes and behavior by emphasizing the work in order to realize the vision and mission of the organization can be that the responses of the local government capacity to align attitudes and behavior by emphasizing the work in order to realize the vision and mission of the organization on the whole locus showed the highest scoring to lowest scoring is Adequate category with a score of 27 or $47 \%$, Self-Sufficient 20 or 34\%, Very Adequate with a score of 11 or $19 \%$. With an average rating of 3.84 or $\log$ on Adequate category.

Furthermore, to see the responses of the local government capacity to initiate and implement 
new tasks without waiting or asking someone else to take action can be seen the responses of the local government capacity to initiate and implement new tasks without waiting or asking others to take action on the overall locus showed the highest scoring to lowest scoring is Adequate with a score of 25 or $43 \%$, Self-sufficient with a score of 21 or $36 \%$, Very Adequate with a score of 7 or $12 \%$, Less Adequate with a score of 4 or $7 \%$, and inadequate with a score of 1 or $2 \%$. With an average rating of 3.57 or $\log$ on Adequate criteria. It can be concluded that the local government capacity to initiate and implement new tasks without waiting or asking others to take actions that are in the good category.

Overall, the average scoring of the variables of the attitude of local government officials Mamuju amounted to 3.62. This means that the overall attitude of the variable sub Mamuju local government officials in the category of Adequate.

\section{Conclusion}

Based on the research, analysis, and discussion on strategies to improve the competence of local government officials in Mamuju as described in Chapter IV, the findings can be summed up as follows:

1. Strategies to improve the competence of government officials in Mamuju from the aspects of knowledge have averaged 3.69 in the category or adequate.

2. Strategies to improve competence of Mamuju district government officials from the aspects of skills have averaged 3.53 in the category or adequate.

3. Strategies to improve the competence of local government officials of Majuju from the aspects of attitude have averaged 3.62 in the category or adequate.

\section{Suggestions}

Based on the conclusions obtained from the analysis and discussion of this research, to meet the strategy of improving the competence of local government officials Mamuju district, the authors suggest:

1. In the aspect of employee knowledge, it is necessary to create a conducive space for employees by providing opportunities for continuing education to be able to think analytically about a complex problem and to be able to come up with creative ideas, encouraging employees to have the ability to perform their duties and responsibilities.

2. In the aspect of skills, it takes the effort and attention of Mamuju's local government leaders to improve education and training relevant to job duties, and the need for increasing employee motivation in order to improve employee productivity, especially in order to stay up to date with the latest technology and information tools.

3. In the aspect of attitude, what is needed is a rational change in employee morals and ethics, so that personnel keep control of their attitudes and behaviors so as to create professionalism and an increase in staff performance. 


\section{Macrothink \\ Journal of Public Administration and Governance \\ ISSN 2161-7104 \\ 2013, Vol. 3, No. 2}

\section{References}

Keith Davis. 1985. Human Behavior at work organizational Behavior, New Delhi: Mc. Grew Hill, Canada.

Kusumastuti, Dyah. , 2003. Based HR Implementation Workshop Competence. Jakarta.

Longenecker, Clinton, O, 1999. Why, organizational Fail: The view from The Frontline Management Decision, 37/6, p. 503 - 513.

Moenir, USA. 1996. Public Service Management in Indonesia. Earth Literacy, Jakarta.

Murley Peter R, 1997. Handbook of customer service Grower, Publishing Limited.

Rivai, Veithzal. , 2004. Performance Appraisal. PT. King Grafindo Persada. Jakarta.

Sinambela, Lijan Poltak, et al. , 2005. Public service reform, Theory, Policy, and Implementation. Earth Literacy. Jakarta.

Like Spencer M \& M. Singe Pencer. 1993. Competence at work Models for Superior Performance, John Wiley \& Sons Inc: New York, Chicherter, Brisbane, Toronto, Singapore.

Sugiono. 1999. Administration research methods, Bandung, Alfabeta.

Zauhar, Soesilo. , 2001. Public Services Administration, an early conversations: Balancing Customer Perception and Expectations, The Free Press, New York.

\section{Documents}

Law Number 32 Year 2004 on Regional Government.

Law Number 43 Year 1999 concerning amendments to the Law Act No. 7 of 1980.

Government Regulation No. 101 of 2000 on Education and Training in Title PNS. 